\title{
Deliberative Spatial Multi-Criteria Evaluation (DSM-CE): Forming Shared Cultural Values
}

\author{
Maria Cerreta $^{(\bowtie)}$ and Simona Panaro \\ Department of Architecture (DiARC), \\ Federico II University of Naples, Via Toledo 402, 80134 Naples, Italy \\ \{maria.cerreta, simona.panaro\}@unina.it
}

\begin{abstract}
The paper introduces a methodological approach for a Deliberative Spatial Multi-Criteria Evaluation (DSM-CE) able to support cultural enhancement, combining deliberative multi-criteria evaluation methods and Geographic Information System (GIS). The purpose concerns the cultural regeneration issue in an interdisciplinary complex decisional context where an interactive decisionmaking process among the different stakeholders is oriented to the identification of shared cultural values. The decision-making process has been elaborated for the historic centre of Naples (Italy), in order to activate a culture-led regeneration process and to recognise in the culture the ability to influence site-specific planning actions.
\end{abstract}

Keywords: Cultural values - Culture-led regeneration · Deliberative multi-criteria analysis $\cdot$ Spatial decision support system

\section{Introduction}

The starting of urban regeneration processes that enhance local resources through sustainable strategies is an open research theme. The economic crisis and the lack of public funding require, indeed, to rethink the chances and forms of action, especially in the historic centres. The attention of local governments towards the development of cultural processes is justified by the need to reposition the city in the global market and simultaneously create an environment suitable to new forms of technology-based economy, creativity, human capital, and ability to innovate (Mercer 2006; Schneider 2010; Ward 2015). Cultural activities are interpreted as an engine for job growth because they are able to build an enabling environment, in which the multi-dimensional forms of creativity (including the sectors of business and technology) can take root and thrive (Florida 2002).

Creativity is considered a means to stimulate economic activity and improve the image of the city, through the specificity and authenticity of places (Zukin 2010) and, for these reasons, is linked to the development of the experience economy (Pine and Gilmore 1999; Poulsson and Kale 2004), and the various forms of cultural tourism. Indeed, thanks to the development of more flexible and innovative strategies, the tourist experience is more difficult to imitate and, therefore, more competitive (Alvarez 2010). The ability of a destination to compete depends not only on its organisational skills but also on its ability to transform the cultural heritage into highly symbolic activities (OECD 2009). 
The focus has, therefore, shifted to the intangible cultural aspects and lifestyle, making even sites without significant architectural and historical heritage potentially competitive (Richards and Wilson 2007).

It follows that, in the past two decades, the concept of tourism has also changed a lot, thanks to technological innovation developments, including tourists forms of involvement in the daily lifestyles. This step is a very delicate point because the clear risk is that an exclusively competitive approach of the experience economy distorts urban lifestyles through their commodification and staging of everyday experiences, without a true meaning (Richards 2011). In a global context, the roots, before the transfer of knowledge and skills, become a key issue for the survival of the cultural identity of places.

On the other hand, the most relevant potential is inherent in relations systems and their spaces, where it is possible to undergo authentic and participative experiences. Indeed, while the traditional economic values were redistributed, in contemporary approaches (civil economy, circular economy, sharing economy) values can be generated within the cooperative and collaborative processes, fielding different forces and productivity (Zamagni and Zamagni 2008). If the city becomes, therefore, a cultural productivity system, the connections that can be put in place will have a much larger identity values system and the presence of hubs, hybrid spaces and areas of contamination in the territory can spark new opportunities since the networking of the context vital resources.

In the processes of transformation and cultural development of the cities, not only "culture" and "creativity" become indispensable, but also the communities and identifying the community-driven processes (Zamagni and Sacco 2006; Ferilli et al. 2012, 2017), viz., the ways to activate the change through interaction with those communities that guide the transformation.

Transformation and management models of value production processes force us to rethink, at the same time, both the private dimension and the public one, considering the mutual innovation opportunity derived from the exchange and interaction of expertise and shared experiences.

Cooperation becomes the main factor of development and hubs are configured as "learning organisation" (Zamagni and Zamagni 2008), in which the creation and sharing of knowledge are the comparative advantage factors, able to leverage the motivations, extrinsic and intrinsic, of all the actors who contribute to their construction. The harmonious coexistence of cooperative and competitive relations among the same actors (public, private and social) facilitates operating the model of "learning organisation", increasing the level of cultural, creative and social productivity.

The activation of a network of urban and regional hubs, complementary and synergistic, allowing pursuit of the economic model of cooperative competition, able to replace the outdated model of positional competition, recognising the potential value of inter-subjectivity (Zamagni and Sacco 2006; Sacco and Crociata 2013).

The methodological study regards the historic centre of the city of Naples, UNESCO site since 1995, and aims at the finding its perceived and shared values by the city's promoters, in order to enhance the local (material and immaterial) heritage as a network. The paper attempts responding to the above issues through the following structure: the first part (Sect. 2) identifies shared values and the difference between 
"social" and "cultural" ones; the second one (Sect. 3) explains the methodological approach of a Deliberative Spatial Multi-Criteria Evaluation and the case study results; the third (Sect. 4) shows discussion and conclusions about the whole process.

\section{Shared Social Values vs Shared Cultural Values: A Value-Focus Perspective}

The research "Culture, Cities and Identity in Europe" (Arfaoui and Heid 2016), developed in collaboration with Culture Action Europe and the Agenda 21 for Culture UCLG, identifies culture as a tool for economic growth, to reconvert cities, to enable integration and inclusion processes, as a pillar of identity for Europe. Many European cities have already recognised the role and importance of culture and creative industries in local development.

Culture is integrated into urban agendas and local development strategies, including such sectors as innovation, branding, tourism and social inclusion. At the same time, culture is considered as both highlighting the participation in a variety of experiences and cultural practices that the capacity of the cultural services of contributing to economic development, including both creative/cultural work in itself, that the arising or related occupations, often also defined as the cultural and creative industry. Culture, as an integrated and driving component, can make a difference in the processes of urban regeneration: renewing the image of the city and its neighbourhoods, fostering pride and a sense of belonging in residents, attracting investment and tourism, improving the quality of life and social cohesion, enabling new job opportunities in the cultural and creative sectors, etc. As a result, the strategies and cultural initiatives are facing an increasingly wide range of policy objectives, becoming more and more a possible success factor in the urban regeneration processes. In this context, culture is seen as the main catalyst of urban regeneration processes, and for this reason, they are defined as culture-led regeneration processes (Fig. 1). This model permits explanation of the relationships between the processes of regeneration and the production of social and human capital, to recognise in the culture the ability to influence specific planning actions, and identify and evaluate the impacts of the processes activated, with particular reference to the human and social dimensions.

The synergistic effect of culture-led regeneration depends, therefore, on how the process is able to create a shared and inclusive social representation, in which the various local communities can learn to expand their ability to interact, creating and sharing information and ideas to cooperate and compete together.

Thus, it expands the audience of subjects potentially interested in collaborating in the construction of an urban renewal strategy that will make the citizens, non-profit institutions, small and medium-sized enterprises, artisans and training bodies, true promoters and protagonists of change. The tourism economy related to cultural heritage and urban renewal processes should be reconsidered in this perspective (Šebová et al. 2014).

The relationship between cultural production and cultural tourism is considered unbalanced, since the latter is mainly defined as the ability to maintain the cities within those attraction mechanisms and enhancement of talent, as part of a tourist offer that can lead to degenerative mechanisms (Sacco et al. 2015). 


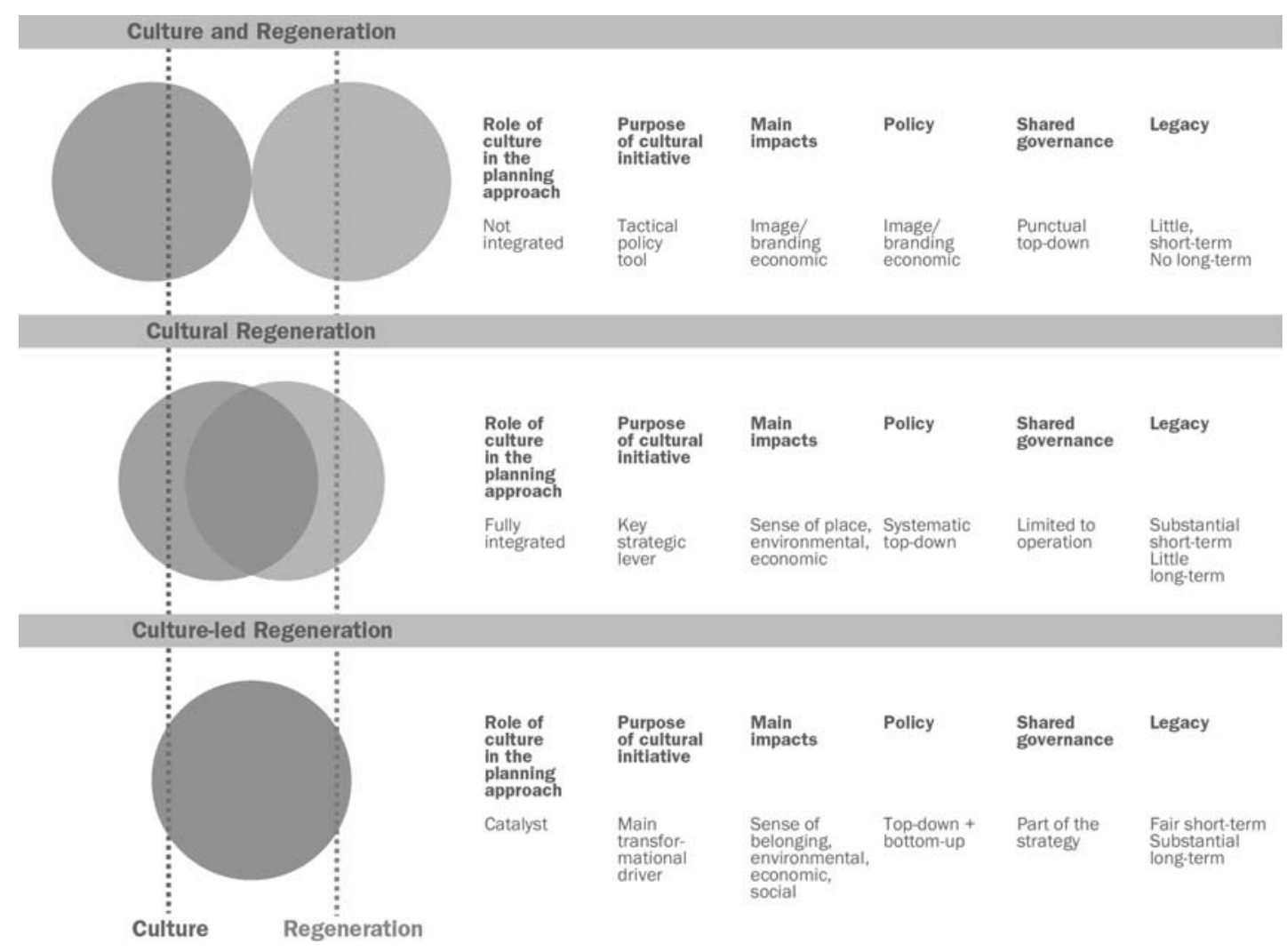

Fig. 1. Culture and regeneration interplay

In this context, we need to encourage the development of cultural capital in the territory, by networking, in a bottom-up approach, the existing projects and ensuring that the different actors have a chance to meet and share their knowledge.

The cultural capital is recognised as a real resource capable of producing value, for which sharing, cooperation and development of new projects related to the economy of culture should be promoted.

It follows that the territorial branding accepts new challenges (Zenker et al. 2010) and the same tourist economy can become more attentive to the possibility of offering authentic experiences and to developing strategies for inclusive urban renewal, avoiding the removal of residents from the centers of interest, and improving well-being and quality of city services.

Cultural productivity and the active involvement of the community in the production process are an integral part of regeneration strategies that cities activated with a "culture-led" approach to local development, to be built on their specific profiles, using culture to differentiate the supply compared to other cities and to increase their competitiveness.

The formation and implementation of collective place brands involve the participation of multiple stakeholders groups (such as public organisations, NGOs, enterprises, investors, residents, and tourists) (Beckman and Zenker 2012), actively engaged in the branding co-creation process, giving their own place brand meaning (Kavaratzis 2012). These branding strategies are aimed at an economic, social and cultural place development, and involve public-private interaction and collaborative processes among various local actors. The collective place branding can become, therefore, an instrument 
of territorial development co-creation, able to trigger cross-sector synergies. It is not just about marketing, but is also considered a collective territorial governance and development project, which sets in motion different processes, depending on various contextual variables, revealing different local dynamics and taking into account three main issues: territorial embeddedness, i.e. place identity, with the anchorage and dynamics of local actors within their territory; local governance and cooperation as driving processes; development policies and public interventions, that set the conditions.

Conventional economic approaches to evaluation, including the welfare economic theory and the evaluation of non-market benefits of the cultural heritage, tend to approach value as unidimensional. Value to society is considered through aggregation of individual valuations, with the assumption that these valuations reflect underlying preferences and values (Klamer 2003). However, such an approach may not capture collective meanings and significance ascribed to cultural resources, missing relevant shared dimensions of value.

In the above perspective, deliberative and participatory approaches to evaluation are increasingly advocated as a way to include the multidimensionality of value within decision-making, considering notions of communal values and collective intentionality. Recent frameworks for evaluation (TEEB 2010; UK NEA 2014) include "shared", "social" or "shared social" values as value categories in order to better manage conflicts over natural resources, assess the social impacts of policy and develop effective management strategies. The same categories can be useful for the management and evaluation of cultural resources.

The concept of shared value has often been used to refer to values that are shared by groups or communities or to refer to cultural values more generally or as synonymous with public values (Sagoff 1986), a result of deliberative and social processes. Indeed, shared values may also refer to values held in common by groups in particular contexts (Kenter et al. 2015).

Whereas the concept of social value refers to the values of a particular community or the cultural values and norms of society, but can also be used to refer to the public interest, values for public goods, altruistic values, values related to welfare or well-being, the willingness-to-pay (WTP) of a group, or values derived through a social process. At the same time, the concept of shared social value refers to subsets or combinations of the various value concepts described above, in relation to deliberative decision-making, characterized by complexity and post-normality (Funtowicz and Ravetz 1993).

Shared social values can be considered as the outcome of processes of effective social interaction, open dialogue and social learning, linked to shared meanings, and depend on the creation activated among cultural groups, as a result of a social learning process (Stagl 2004). These methods underline that values related to complex goods are not pre-formed, and need to be constructed through a transformative process of deliberation and learning (Christie et al. 2012; Kenter et al. 2011). According to Kenter et al. (2015), overcoming the limitations of neoclassical economic valuation in assessing shared, social and shared social values, deliberative and interpretive approaches for their elicitation incorporate notions of common and cultural importance through social and collaborative processes. 


\section{Deliberative Spatial Multi-Criteria Evaluation for the Naples Historic Center (Italy)}

The research aims at developing a methodology for tracing the potentials of the historical centre of the city of Naples. It was, thus, elaborated an interpretational model of the context, which analyses the value in use, value of non-use and the intrinsic values (Fusco Girard and Nijkamp 1997), in order to identify the shared ones (Porter and Kramer 2011), the ongoing dynamics and the actions that could enable a culture-led regeneration (Vickery 2007; UNESCO 2009).

Therefore, once defined the potentials of the historic city centre, the research intends to suggest a strategy for the enhancement of its cultural heritage as a network. More specifically, the study has been led within the "Social Network of Historical District Entity - SNECS" research project, University of Naples Federico II, Department of Architecture (DiARC).

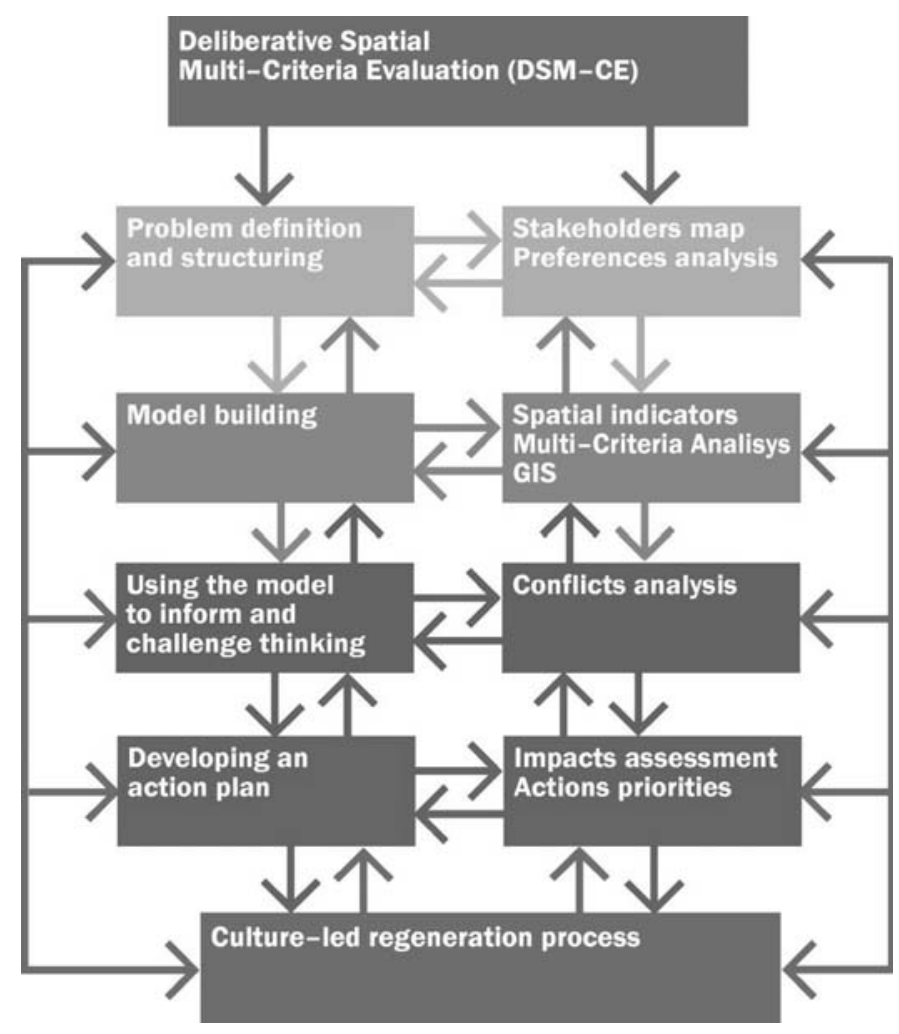

Fig. 2. The methodological approach

The research focuses on improving the stakeholders involvement into the new enhancing policies of Naples' historical centre, with the wider goal of structuring a functional methodology for inclusive decision-making processes. This methodology falls within four stages, of which the first two have already been tested (Fig. 2):

- Problem definition and structuring. It includes the institutional analysis aimed at the identification of relevant stakeholders for the studied issue, the practical investigation carried out through semi-structured and in-depth interviews, the processing 
of the interviews and the preferences to clarify the terms of the decisional problem (i.e. the criteria and the network of potential actors, places and actions with the related levels of relevance).

- Model building. It includes the selection of indicators pertinent to the decisional problem, the elaboration of spatial indexes through GIS data processing, the recognition of suitable areas within Naples historical centre by the use of the WLC method, the definition of synergetic actions through the analysis of conflicts and coalitions carried out with the support of the NAIADE method.

- Using the model to inform and challenge thinking. It consists in consulting the local actors for checking the strategic actions, their localisation in order to understand their risks and potential consequences, and for implementing them.

- Developing an action plan. It regards the assessment of the impacts, the definition of a scale of preferences for the actions and their planning during the time.

In the methodology have been set two different consulting stages of the local actors, the first one (phase 1) to structure the decisional problem, the second one (phase 3) to check and implement the decisional process. This work is still in progress, and, below, will be shown the results of stages 1 and 2 .

\subsection{Problem Definition and Structuring}

In the first phase of the methodological approach, through the institutional analysis (Lapassade 2006), a heterogeneous group of stakeholders has been selected. Apart from people with institutional roles related to the protection/knowledge/promotion of cultural heritage, the research also addressed to operators offering an alternative form of visiting the historical centre or private citizens that host visitors and tourists in their private properties, thanks to web platforms (such as Airbnb). The stakeholders' map was drawn up by considering the following categories:

- Promoters of cultural heritage;

- Operators of the creative, leisure and tourism industry;

- Experts of the SNECS research project.

The operators in the tourism/leisure industry have been interviewed through semi-structured interviews, while experts and advisers through in-depth interviews.

The processing of soft data was led through a semantic analysis (Perea and Rosa 2002; Lepore and Stone 2007), which allowed to disclose the relevant issues and the preferences of the interviewees, useful, in addition, to trace the guidelines and identify the criteria for the study of the context.

The overall of the operators interviewed affirm the need to give visitors the opportunity to discover places outside the traditional routes. There is as a mater of fact, a widespread rediscovery of the historical cultural heritage of the city, due to the rise of tourists' number in recent years. However, the touristic promotion of the city is still 
limited to the traditional sights. On the contrary, the citizenship is showing more and more interested in broadening their knowledge of the local heritage to less known sights and innovative forms of cultural promotion (e.g. night museum visits; speleological visits to the lower ground of Castel Nuovo, a kayak tour along the city's seashore; a tour through the Underground stations). Nevertheless, these events are not regularly arranged or widely sponsored, apart from the month of May dedicated to the cultural heritage promotion by the local Institutions, "Maggio dei Monumenti". In fact, during this month a great deal of the local cultural events are officially scheduled, and it becomes possible to visit places normally not open to the public.

Among the operators, in particular, the hosts of Airbnb platform interviewed are already promoting the city in alternative ways, since they recommend to their guest visiting places and events they would attend, very often away from the most touristic sites. Their answer to the question "Find a motto to promote your city?" has been, indeed, "Experience Naples like me that was born and raised here".

The Experts, as well, suggest to give more relevance to the cultural activities and events focused on strengthen the identity and sense of belonging to the city, and to develop new modes of interaction with the huge cultural and archaeological heritage of the city by the use of IT systems for communicating knowledge and the specificities of the context. However, tangible proposals in this field are only made by specialists who are currently working on an enhancing plan of city's heritage in the Art Underground Stations, by testing and developing new modes of representation (e.g. video mapping).

Another key point regard public transports and mobility (pedestrian routes or underground lines, and their intermodal integration). On the one hand, some railways and metro lines are seen as good transport links to most popular hotspots for the city life, on the other hand, mobility services on roads, including bus services, are considered inadequate. Many interviewees mention indeed their difficulties to reach some areas of the city centre, characterized by a high concentration of the cultural heritage, by public transports as a reason for their alienation from the city's cultural life; on the contrary the opening of new underground stations in the historic centre has determined new bustling zones in town.

In particular, in the city of Naples for the extension of the underground Line 1, also called "Metropolitana dell'Arte, Architettura e Archeologia" (the Art, Architecture and Archaeology Underground), the stations have been placed close to the areas of the highest cultural interest within the historic city centre. However, there is much to be done for the intermodal integration of all modes of transports and the improvement of transport links to the city centre, especially for some districts.

Through the identification of same keywords and their relative returning in the interviews have been, thus, recognized the main topics and the guidelines for describing the local context in its characteristic features, in particular: the local services' system (namely cultural and touristic services, public services, commercial services, recreational and restaurant services); the local public transports, the innovation and research; the safety standards. These criteria are, thus, according to interviewees, the key points for designing actions of urban regeneration intended to enhance the city's (material and immaterial) cultural heritage. 


\subsection{Model Building}

In the building of the methodological model was given prominence to a set of indicators capable of describing the criteria in details. They are mostly based on institutional sources, apart from the safety parameter, which was elaborated on a mapping of local crime realised by a local newspaper. The mapping is a VGI, Volunteered Geographic Information (Goodchild 2012); they are maps voluntarily created by the users and are freely available online, for this reason, are often used despite needing a quality assurance checking. This group of indicators, selected on each criterion, is shown in Table 1.

Table 1. Criteria and indicators

\begin{tabular}{|c|c|c|c|c|c|}
\hline Criteria & Indicators & $\begin{array}{l}\text { Measure } \\
\text { unit }\end{array}$ & $\begin{array}{l}\text { Territorial } \\
\text { coverage }\end{array}$ & Year & Source \\
\hline $\begin{array}{l}\text { Tourist } \\
\text { services }\end{array}$ & $\begin{array}{l}\text { Number of employees in } \\
\text { the hospitality industry }\end{array}$ & Number & $\begin{array}{l}\text { Cadastral } \\
\text { sections }\end{array}$ & 2011 & ISTAT \\
\hline \multirow[t]{3}{*}{$\begin{array}{l}\text { Cultural } \\
\text { services }\end{array}$} & $\begin{array}{l}\text { Number of creative, artistic } \\
\text { and entertainment activities }\end{array}$ & Number & $\begin{array}{l}\text { Cadastral } \\
\text { sections }\end{array}$ & 2011 & ISTAT \\
\hline & $\begin{array}{l}\text { Number of libraries, } \\
\text { archives and other cultural } \\
\text { activities }\end{array}$ & Number & $\begin{array}{l}\text { Cadastral } \\
\text { sections }\end{array}$ & 2011 & ISTAT \\
\hline & Number of cultural sites & Number & Points & 2015 & $\begin{array}{l}\text { Comune di } \\
\text { Napoli }\end{array}$ \\
\hline $\begin{array}{l}\text { Leisure } \\
\text { Services }\end{array}$ & $\begin{array}{l}\text { Number of recreational and } \\
\text { amusement activities }\end{array}$ & Number & $\begin{array}{l}\text { Cadastral } \\
\text { sections }\end{array}$ & 2011 & ISTAT \\
\hline $\begin{array}{l}\text { Commercial } \\
\text { activities }\end{array}$ & $\begin{array}{l}\text { Number of stores and } \\
\text { commercial activities }\end{array}$ & Number & $\begin{array}{l}\text { Cadastral } \\
\text { sections }\end{array}$ & 2011 & ISTAT \\
\hline \multirow[t]{2}{*}{$\begin{array}{l}\text { Catering } \\
\text { services }\end{array}$} & $\begin{array}{l}\text { Number of restaurants and } \\
\text { catering services }\end{array}$ & Number & $\begin{array}{l}\text { Cadastral } \\
\text { sections }\end{array}$ & 2011 & ISTAT \\
\hline & Number of cafè, bars, pubs & Number & $\begin{array}{l}\text { Cadastral } \\
\text { sections }\end{array}$ & 2011 & ISTAT \\
\hline $\begin{array}{l}\text { Public } \\
\text { transport }\end{array}$ & $\begin{array}{l}\text { Number of underground } \\
\text { station }\end{array}$ & Number & Points & 2017 & $\begin{array}{l}\text { Comune di } \\
\text { Napoli }\end{array}$ \\
\hline \multirow[t]{4}{*}{$\begin{array}{l}\text { Public } \\
\text { service }\end{array}$} & Number of post office & Number & $\begin{array}{l}\text { Cadastral } \\
\text { sections }\end{array}$ & 2011 & ISTAT \\
\hline & $\begin{array}{l}\text { Number of public office and } \\
\text { police stations }\end{array}$ & Number & $\begin{array}{l}\text { Cadastral } \\
\text { sections }\end{array}$ & 2011 & ISTAT \\
\hline & $\begin{array}{l}\text { Number of schools and } \\
\text { educational services }\end{array}$ & Number & $\begin{array}{l}\text { Cadastral } \\
\text { sections }\end{array}$ & 2011 & ISTAT \\
\hline & $\begin{array}{l}\text { Number of hospitals and } \\
\text { health services }\end{array}$ & Number & $\begin{array}{l}\text { Cadastral } \\
\text { sections }\end{array}$ & 2011 & ISTAT \\
\hline Innovation & $\begin{array}{l}\text { Number research and } \\
\text { development activity }\end{array}$ & Number & $\begin{array}{l}\text { Cadastral } \\
\text { sections }\end{array}$ & 2011 & ISTAT \\
\hline $\begin{array}{l}\text { Safety } \\
\text { standards }\end{array}$ & Number of criminal acts & Number & Points & 2015 & $\begin{array}{l}\text { napolitoday. } \\
\text { it }\end{array}$ \\
\hline
\end{tabular}


The indicators, thus selected, have been later worked out in order to identify for each criterion a single or more indexes that would provide an overall picture of the city's historic centre. By comparing the historic centre's data with those of the entire city of Naples, it was possible to elaborate the indexes for assessing the vitality level of the historic centre in comparison with the other city's areas.

Reporting the data in the GIS system allowed, lastly, their spatial simplification, which itself enabled to better understand the current phenomena and support, in the further stages, the decisional process on where to locate future actions. Through data processing, normalization and reclassification the following indexes have been created:

- ID01, the density of public services, which shows the number of public services within a specific cadastral section, compared with the number of public services in the city;

- ID02, the density of catering services, which shows the number of catering services within a specific cadastral section, compared with the number of the catering services in the city;

- ID03, the local specialization for the hospitality industry, which shows the number of employees in hotel industry within a specific cadastral section compared with the number of employees in the same field in the entire city area;

- ID04, the density of creative and leisure activities, which shows the number of creative and leisure activities within the specific cadastral sections, compared with the number of creative and leisure activities in all the city;

- ID05, index of accessibility to services for each cadastral section. It regards the total number services offered in the cadastral section according to the distance of the area to the closest underground station;

- ID06, the density of cultural sites, which shows the number of cultural sites and the activity of public sites using the Kernel density spatial analysis;

- ID07, the density of criminal acts, which shows the number of murders, muggings, prostitutes using the Kernel density spatial analysis.

- ID08, the density of stores and commercial activities, which shows the number of stores and commercial activities within the specific cadastral sections, compared with the number of stores and commercial activities in the city.

The spatial indexes allow understanding the distribution of the services, the activities and the cultural sites, as well as the level of security. The density maps achieved let describe the geography and the intensity of relations concentrating around some specific areas, which are already attractive places for the historical city centre (city sights). The information processed in the previous steps has been arranged according to a matrix of assessment built in the following categories: groups, goals, actions, spatial indexes. At this point, from the interviewees' preferences have been obtained the weights of the spatial indexes so as to develop a preference map of the historic centre, making use of the WLC multi-criteria method (Weighted Linear Combination) integrated with the GIS system. 
The multi-criteria analysis tools integrated with the GIS software allowed to develop an evaluation map, which relates geographic data to value judgements (Malczewski 2006; Montrone et al. 2010; Bonifazi et al. 2016), showing the areas of potentiality (green) and the critical areas (red) (Fig. 3). Through the assigning of weight, the preferences of the interviewees have been related to the resources of the historical city centre.

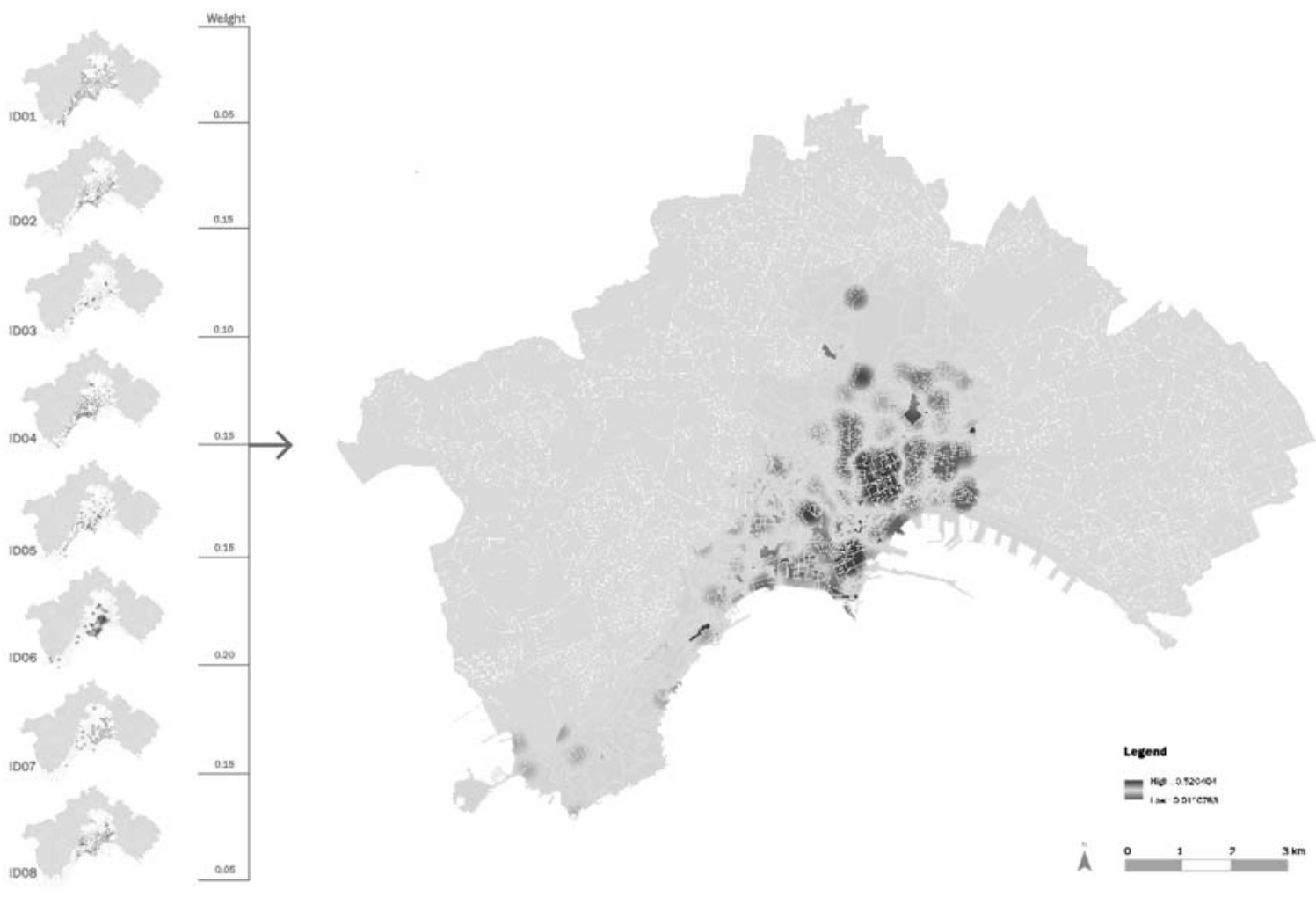

Fig. 3. The evaluation map (Color figure online)

This evaluation map allows to summarize the studied issues and offers a supporting tool for the subsequent consultation of the relevant stakeholders in the next stages. In order to support the consultation, it was also carried out the analysis of the conflicts and coalitions among the stakeholders by using the NAIADE method (Novel Approach to Imprecise Assessment and Decision Environments, Munda 1995).

NAIADE, through the equity matrix and a sequence of mathematical reductions, enables to build the dendrogram of coalitions showing possible alliance formation among social groups (Table 2; Fig. 4).

In such manner, were found a series of synergistic actions easily shared by the stakeholders. At this stage, it was elaborated a sample of the strategic map that locates the synergistic actions, acquired with the NAIADE method, according to the preference areas found with the WLC analysis. 
Table 2. The equity matrix

\begin{tabular}{l|l|l|l}
\hline Alternatives & \multicolumn{2}{l}{ Stakeholders } \\
\hline Strategic actions & Promoters & Operators & Experts \\
\hline Start an info-point & Very Good & Moderate & Good \\
\hline Improve transports and mobility & Good & Very Good & Good \\
\hline Increase services & Moderate & Good & Moderate \\
\hline Improve security & Moderate & Good & Moderate \\
\hline Support communities & Good & Very Good & Moderate \\
\hline Direct tourism & More o Less Good & Moderate & Very Good \\
\hline Build a picture of the city & Very Good & More o Less Good & Very Good \\
\hline Promote new routes and itineraries & Moderate & Very Good & Moderate \\
\hline Monitor the results & Very Good & Moderate & Good \\
\hline Increase the use of technology & Good & Moderate & Very Good \\
\hline Start up a cultural hub & Very Good & Moderate & Moderate \\
\hline
\end{tabular}

\section{Dendrogram of Cosltion Formation Procese}

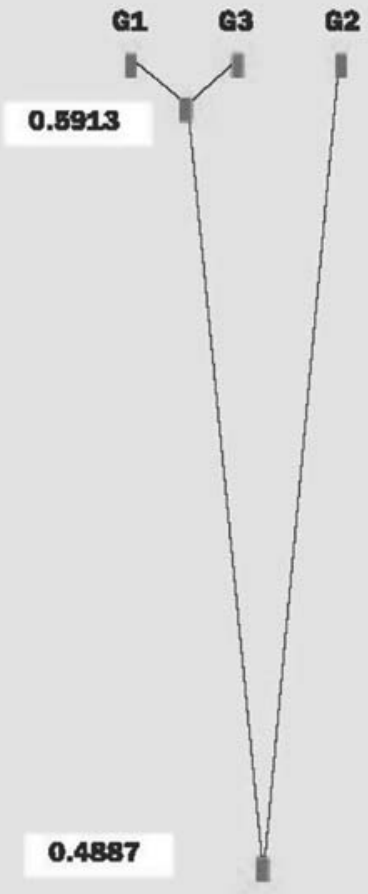

\section{Altematives}

A Start an info-point

B Improve transports and mobllity

C Increase services

D Improve security

E Support communities

F Direct tourism

G Bulld a plcture of the clty

H Promote new routes and itineraries

I Monitor the results

Jincrease the use of technology

K Start up a cultural hub

\section{Valo diseram}

(G3, G1)

$\begin{array}{ll}\text { G } & 0,05 \\ \text { J } & 0,16 \\ \text { I } & 0,16 \\ \text { A } & 0,16 \\ \text { B } & 0,22 \\ \text { F } & 0,25 \\ \text { K } & 0,45 \\ \text { E } & 0,48 \\ \text { C } & 0,64 \\ \text { D } & 0,64 \\ \text { H } & 0,64\end{array}$

(G2)

$\begin{array}{cc}\text { B } & 0,04 \\ \text { E } & 0,04 \\ \text { H } & 0,04 \\ \text { D } & 0,15 \\ \text { C } & 0,15 \\ \text { G } & 0,25 \\ \text { A } & 0,45 \\ \text { F } & 0,45 \\ \text { I } & 0,45 \\ \text { J } & 0,45 \\ \text { K } & 0,45\end{array}$

\section{Groups}

Q1 Promoters G2 Operators Q3 Experts

$x$ Vetoed alternative

$\mathrm{X}$ Altemative vetoed by this coalition

Fig. 4. The dendrogram of coalitions and the actions ranking 
This strategic map considers the potentialities and the critical points of local resources and contributes thus to explicate stakeholders' preferences concerning the resources of the historical centre, providing a proposal capable of limiting potential conflicts, combining objective and subjective analysis (Fig. 5).

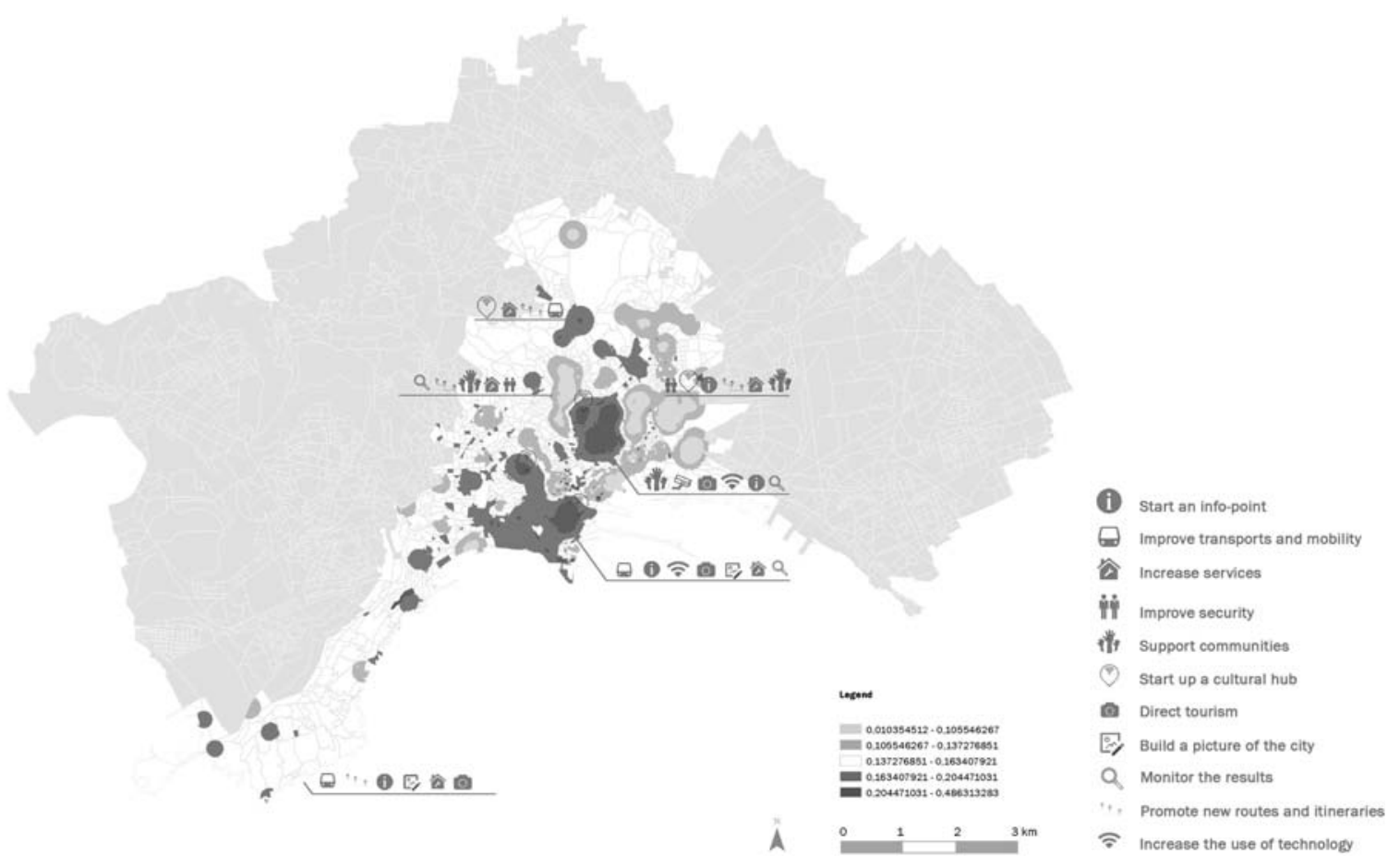

Fig. 5. The strategic map

These two methodological phases have allowed understanding the goals of every group of actors, taking into account the potential conflicts and the opportunities related to the localization of the resources, formerly analysed in the previous stages.

In the following stages, these issues will be properly discussed and examined with the stakeholders, furtherly extending the decisional process and defining a site-specific action plan.

\section{Conclusions and Discussion}

The experimental methodology elaborated in the Naples historic center intends to start a fruitful dialogue among stakeholders interested in a culture-led regeneration of the city. The purpose of the research is, thus, to construct an inclusive decisional process, whose key steps are to outline a framework of knowledge suitable to the different stakeholder's objectives and to identify shared strategic actions.

Stakeholders' preferences have, therefore, led the analysis of the existing local resources, and the shared actions for the enhancement of the historic centre have been correlated to them. In such manner, an interpretative model of the ongoing potentials was built in support of the following stage of consultation and openness of the decision-making process. 
A growing and widespread awareness, which stems from practice and experience, suggests how the culture-led renovation fosters the establishment of new social and creative places. However, unless they are properly included into the economic and social trends of the place, they could even worsen social exclusion and alienation (Zukin 2010). Therefore, finding the conditions for culture to be economically advantageous and socially sustainable is a key point in the study (Sacco et al. 2014). On the one hand, local governments and investors should focus on the economic results of their investments in art and culture; on the other hand, local communities should promote actions and cultural activities aimed at realizing new social, economic and management modes. These different attitudes tend to merge very often, overlapping top-down and bottom-up approaches. A sustainable example of culture-led urban regeneration requires, indeed, to integrate the two approaches, enabling communication and cooperation among the parties and different involved stakeholders. This leads to a hybrid approach that attempts to consider the complexity belonging to a culture-led development process through interdisciplinary tools (Sacco and Crociata 2013). Culture is becoming a new platform, capable of generating social values along with economic values, taking on different roles: coordinate organically integrated innovation processes; realize new ways of active citizenship based on shared knowledge; and outline new standards of wealth. Thus, it is crucial to involve as many groups of people as possible in the regeneration process, in order to use their strategic integration and balance their systemic effects, combining different methods. This is a model of development that attracts resources from outside, both talents and creative companies; it encourages the competitiveness among the most qualified local resources; and it is based on citizens' involvement and social cohesion, paying specific attention to the promotion of actions that foster the community's capability-building and social enterprises (Sacco et al. 2012, 2014; Sassano et al. 2016; Cannavacciuolo et al. 2017). A culture-led regeneration process needs social and economic conditions to let culture trigger the change.

The inclusive regeneration processes and the integrated enhancement of Naples historical city should steadily encourage those activities and areas of interest where culture, creativity and economy cooperate for the development of the local community in productive ways. According to the UN-Habitat (2004), in order to feed creativity, cities should have a generous and inclusive culture, an attitude of openness and integration. It has been defined with the word "moxie" the ability to face adversities with courage. The word denotes feelings such as bravery, strength, energy and curiosity for all that is different and new. It becomes a strong drive for change that can trigger innovating processes.

Acknowledgements. This study has been supported by "Social Network of Historical District Entity - SNECS" research project, University of Naples Federico II, Department of Architecture (DiARC), Project code: PON03PE_00163_1 - MIUR 3972 del 20/11/2014. 


\section{References}

Mercer, C.: Cultural planning for urban development and creative cities (2006). http://www. burgosciudad21.org/adftp/Shanghai_cultural_planning_paper.pdf

Schneider, B.: Cities and Regions: their cultural responsibility for Europe and how they can fulfil it. A manual, A soul for Europe. TOGETHER project, European Parliament (2010). http:// www.asoulforeurope.eu/sites/www.asoulforeurope.eu/files/media_pdf/Manual\%20Cities\% 20\%26\%20Regions.pdf

Ward, J.: Report on the role of intercultural dialogue, cultural diversity and education in promoting EU fundamental values. European Parliament - Committee on Culture and Education (2015). http://www.europarl.europa.eu/sides/getDoc.do?pubRef=-//EP//TEXT +REPORT+A8-2015-0373+0+DOC+XML+V0//EN

Florida, R.: The Rise of the Creative Class: And How It's Transforming Work, Leisure, Community and Everyday Life. Basic Books, New York (2002)

Zukin, S.: Naked City: The Death and Life of Authentic Urban Places. Oxford University Press, Oxford (2010)

Pine, J., Gilmore, J. (eds.): The Experience Economy. Harvard Business School Press, Boston (1999)

Poulsson, S.H.G., Kale, S.H.: The experience economy and commercial experiences. Mark. Rev. 4, 267-277 (2004)

Alvarez, M.D.: Creative cities and cultural spaces: New perspectives for city tourism. Int. J. Cult. Tourism Hospitality Res. 4, 171-175 (2010)

OECD: The impact of culture on tourism. OECD, Paris (2009)

Richards, G., Wilson, J. (eds.): Tourism, Creativity and Development. Routledge, London (2007)

Richards, G.: Creativity and tourism: The state of the art. Ann. Tourism Res. 38(4), 1225-1253 (2011)

Zamagni, S., Zamagni, V. (eds.): La cooperazione. Il Mulino, Bologna (2008)

Zamagni, S., Sacco, P.L. (eds.): Teoria economica e relazioni interpersonali. Il Mulino, Bologna (2006)

Ferilli, G., Sacco, P.L., Blessi, G.T.: Cities as creative hubs: From instrumental to functional values of culture-led local development. In: Girard, L.F., Nijkamp, P. (eds.) Sustainable City and Creativity: Promoting Creative Urban Initiatives, pp. 110-124. Ashgate, London (2012)

Ferilli, G., Sacco, P.L., Tavano, B.G., Forbici, S.: Power to the people: When culture works as a social catalyst in urban regeneration processes (and when it does not). Eur. Plan. Stud. 25(2), $1-18$ (2017)

Sacco, P.L., Crociata, A.: Conceptual regulatory framework for design and evaluation of complex, participative cultural planning strategies. Int. J. Urban Reg. Res. 37(5), 1688-1706 (2013)

Arfaoui, M., Heid, K.: Culture, Cities and Identity in Europe, European Economic and Social Committee, Brussel (2016). http://www.eesc.europa.eu

Šebová, M., Džupka, P., Hudec, O., Urbančíková, N.: Promoting and financing cultural tourism in Europe through European capitals of culture: A case study of Košice, European capital of culture 2013. Economic Interferences XVI(36) (2014)

Sacco, P., Ferilli, G., Blessi, G.T. (eds.): Cultura e sviluppo locale. Verso il distretto culturale evoluto. Il Mulino, Bologna (2015)

Zenker, S., Knubben, E., Beckmann, S.C.: Your city, my city, their city, our city: Different perceptions of a place brand by diverse target groups. In: 6th International Conference Thought Leaders in Brand Management, Lugano, Switzerland, 18-20 April 2010 
Beckman, B., Zenker, S.: Place branding: A multiple stakeholder perspective. In: 41st European Marketing Academy Conference, Lisbon, Portugal, 22-25 May 2012

Kavaratzis, M.: From “necessary evil” to necessity: stakeholders' involvement in place branding. J. Place Manage. Dev. 5(1), 7-19 (2012)

Klamer, A.: A pragmatic view on values in economics. J. Econ. Methodol. 10, 191-212 (2003)

TEEB: The economics of ecosystems and biodiversity: The ecological and economic foundations. Earthscan, London (2010)

UK National Ecosystem Assessment: UK National Ecosystem Assessment Follow-on. Phase: Synthesis Report. UNEP-WCMC, Cambridge (2014)

Sagoff, M.: Values and preferences. Ethics 96, 301-316 (1986)

Kenter, J.O., O’Brien, L., Hockley, N., Ravenscroft, N., Fazey, I., Irvine, K.N., Reed, M.S., Christie, M., Brady, E., Bryce, R., Church, A., Cooper, N., Davies, A., Evely, A., Everard, M., Fish, R., Fisher, J.A., Jobstvogt, N., Molloy, C., Orchard-Webb, J., Ranger, S., Ryan, M., Watson, V., Williams, S.: What are shared and social values of ecosystems? Ecol. Econ. 111, 86-99 (2015)

Funtowicz, S.O., Ravetz, J.R.: Science for the post-normal age. Futures 25, 739-755 (1993)

Stagl, S.: Valuation for sustainable development: The role of multicriteria evaluation. Vierteljahrsh Wirtsch Forsch 73, 53-62 (2004)

Christie, M., Fazey, I., Cooper, R., Hyde, T., Kenter, J.O.: An evaluation of monetary and non-monetary techniques for assessing the importance of biodiversity and ecosystem services to people in countries with developing economies. Ecol. Econ. 83, 69-80 (2012)

Kenter, J.O., Hyde, T., Christie, M., Fazey, I.: The importance of deliberation in valuing ecosystem services in developing countries: Evidence from the Solomon Islands. Glob. Environ. Change 21, 505-521 (2011)

Fusco Girard, L., Nijkamp, P.: Le valutazioni per lo sviluppo sostenibile della città e del territorio. Angeli, Milano (1997)

Vickery, J.: The Emergence of Culture-led Regeneration: A Policy Concept and its Discontents. Warwick, Centre for Cultural Policy Studies (2007). http://wrap.warwick.ac.uk/36991/1/ WRAP_Vickery_ccps.paper9.pdf

UNESCO: Measuring the Economic Contribution of Cultural Industries (2009). http://www.uis. unesco.org/culture/Documents/FCS-handbook-1-economic-contribution-culture-enweb.pdf

Lapassade, G.: Groupes, organisations, institutions. Anthropos, Paris (2006)

Perea, M., Rosa, E.: The effects of associative and semantic priming in the lexical decision task. Psychol. Res. 66, 180-194 (2002)

Lepore, E., Stone, M.: Logic and semantic analysis: Philosophy of logic. In: A volume in Handbook of the Philosophy of Science, pp. 173-204 (2007)

Goodchild, M.F., Li, L.: Assuring the quality of volunteered geographic information. Spatial Stat. 1, 110-120 (2012)

Malczewski, J.: GIS-based multicriteria decision analysis: A survey of the literature. Int. J. Geogr. Inf. Sci. 20(7), 703-726 (2006)

Montrone, S., Perchinunno, P., Torre, C.M.: Analysis of positional aspects in the variation of real estate values in an Italian southern metropolitan area. In: Taniar, D., Gervasi, O., Murgante, B., Pardede, E., Apduhan, Bernady O. (eds.) ICCSA 2010. LNCS, vol. 6016, pp. 17-31. Springer, Heidelberg (2010). doi:10.1007/978-3-642-12156-2_2

Bonifazi, A., Sannicandro, V., Attardi, R., Cugno, G., Torre, C.M.: Countryside vs city: A user-centered approach to open spatial indicators of urban sprawl. In: Gervasi, O., Murgante, B., Misra, S., Rocha, A.M.A.C., Torre, C.M., Taniar, D., Apduhan, B.O., Stankova, E., Wang, S. (eds.) ICCSA 2016. LNCS, vol. 9789, pp. 161-176. Springer, Cham (2016). doi:10.1007/978-3-319-42089-9_12 
Munda, G.: Multicriteria Evaluation in a Fuzzy Environment: Theory and Applications in Ecological Economics. Physica-Verlag, Heidelberg (1995)

Sacco, P.L., Ferilli, G., Tavano, B.G.: Understanding culture-led local development: A critique of alternative theoretical explanations. Urban Stud. 51(13), 2806-2821 (2014)

Sacco, P.L., Ferilli, G., Blessi, G.T.: Culture 3.0: A new perspective for the EU active citizenship and social and economic cohesion policy. In: The Cultural Component of Citizenship: An Inventory of Challenge. European House for Culture. Access to the Culture Platform, pp. 195-213 (2012)

Sassano, G., Graziadei, A., Amato, F., Murgante, B.: Involving citizens in the reuse and regeneration of urban peripheral spaces. In: Nunes Silva, C., Local, B.J. (eds.) Government and Urban Governance in Europe, pp. 193-206. Springer, Heidelberg (2016)

Cannavacciuolo, L., Iandoli, L., Ponsiglione, C., Zollo, G.: Learning by failure vs learning by habits: entrepreneurial learning micro-strategies as determinants of the emergence of co-located entrepreneurial networks. Int. J. Entrep. Behav. Res. 23(3), 524-546 (2017)

UN-Habitat: State of the World's Cities Report 2004/2005. Globalization and Urban Culture. United Nations Human Settlements Programme, Earthscan, London (2004) 